\title{
Called to Action: Environmental Restoration by Artists
}

\author{
Lillian Ball
}

\begin{abstract}
I organized the exhibit Called To Action to present works by artists who not only comment upon environmental issues but also intercede to halt degradation and nurture environmental health. This exhibit ran May through June 2007 at Art Sites, a gallery in Riverhead, New York, and was conceived of with Glynis Berry, a green architect and the gallery owner. The exhibit featured twelve projects, six of which were selected by Ecological Restoration to be presented here along with the artists' descriptions. All of the exhibited projects reflect the work of artists who are passionately involved in processes that restore different ecosystems worldwide. The artists, working with scientists, government officials, and planners, aim to escape the confines of the "white box" and actually influence land management and policy. From diverse backgrounds, these artists have been inspired by an urgent need to address environmental destruction. That is why I consider the artists in this exhibition to be "called to action."

Some of the artists' projects are commissioned, but for others the inspiration comes from an intimate connection with local circumstances. Artist Richard Kirk Mills's involvement in the Teaneck Conservancy, for example, grew out of his relationship to the neighborhood where he lives, literally his own backyard. Mierle Laderman Ukeles, a pioneer in art-community interface, is artist in residence at the Fresh Kills Landfill on Staten Island. Her six-channel video piece with Kathy Brew and Roberto Guerra combines footage of the landfill, interviews with city officials and biologists, and her plans for future wetland restoration. An Argentine collaborative group, Ala Plastica, presents images that guide viewers through the multifaceted cultural forces surrounding the cleanup of a 1999 oil spill in the Rio de la Plata community. Work this ambitious is truly interactive.

An inspirational roundtable discussion with artists, planners, landscape designers, scientists, and government officials from the Eastern Long Island community extended the exhibition's potential. The discussion explored public art perceptions, green building philosophies, and possible nonprofit solutions. The exhibition and roundtable aimed to raise consciousness about ways to integrate this kind of art with specific local applications. Brownfields can be restored, globally rare ecosystems can be preserved, and biodiversity can be maintained in the landscape. The artists in Called To Action are creatively negotiating the fertile spaces in between disciplines to help make this work possible. The ultimate goal for the ideas in this exhibition is to enter the public domain, to stimulate active involvement, and to effect change through envisioning alternatives.
\end{abstract}

\section{Magdalena Oil Spill}

\section{Rafael Santos / Ala Plastica (Argentine} collaborative group)

On January 15th, 1999, a cargo ship and an oil tanker collided in the Rio de La Plata, near Magdalena, Argentina. The accident occurred close to the mouth of the river in a 600-m wide navigation channel. By January 20th, $16 \mathrm{~km}$ of riverbanks were covered with 5000 tons of oil, devastating plants and animals and poisoning the water and community, part of which is a UNESCO Biosphere Reserve.

Ecological Restoration Vol. 26, No. 1, 2008 ISSN 1522-4740 E-ISSN 1543-4079 (O) 2008 by the Board of Regents of the University of Wisconsin System.

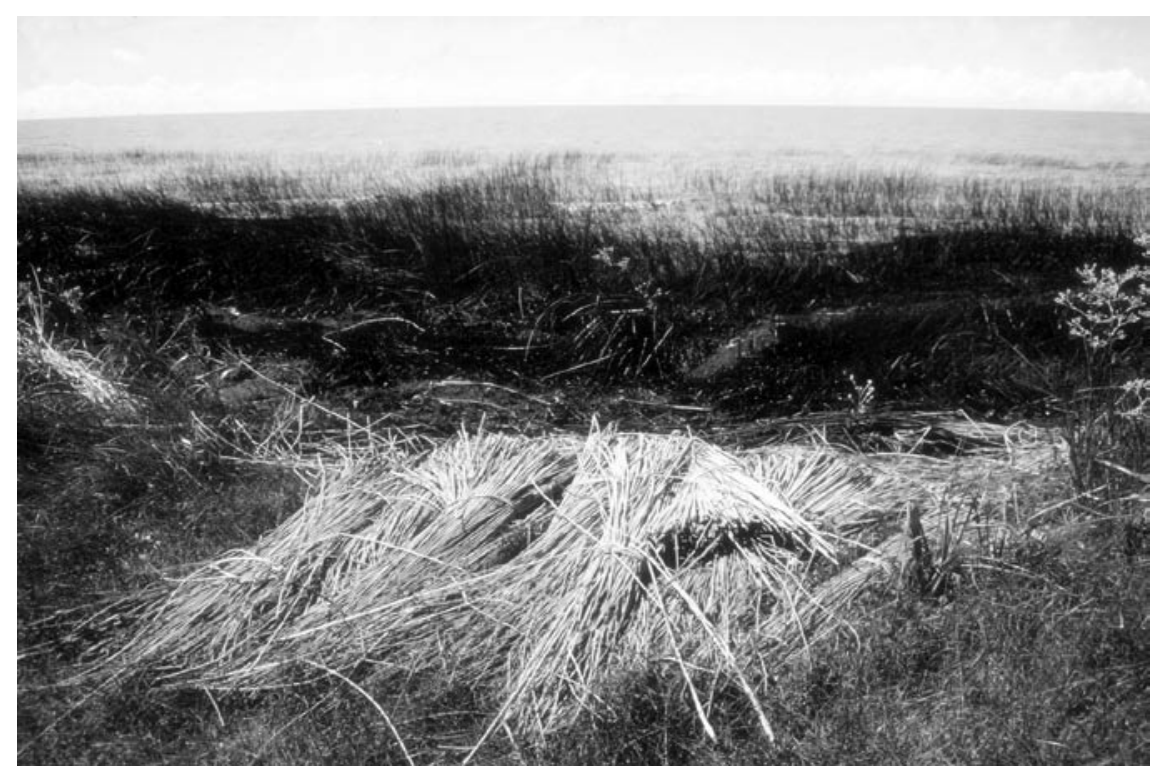

"Last Reed Harvest," taken to document the impacts of an oil spill on the human and natural communities of Magdalena, Argentina. Photo courtesy of Ala Plastica 


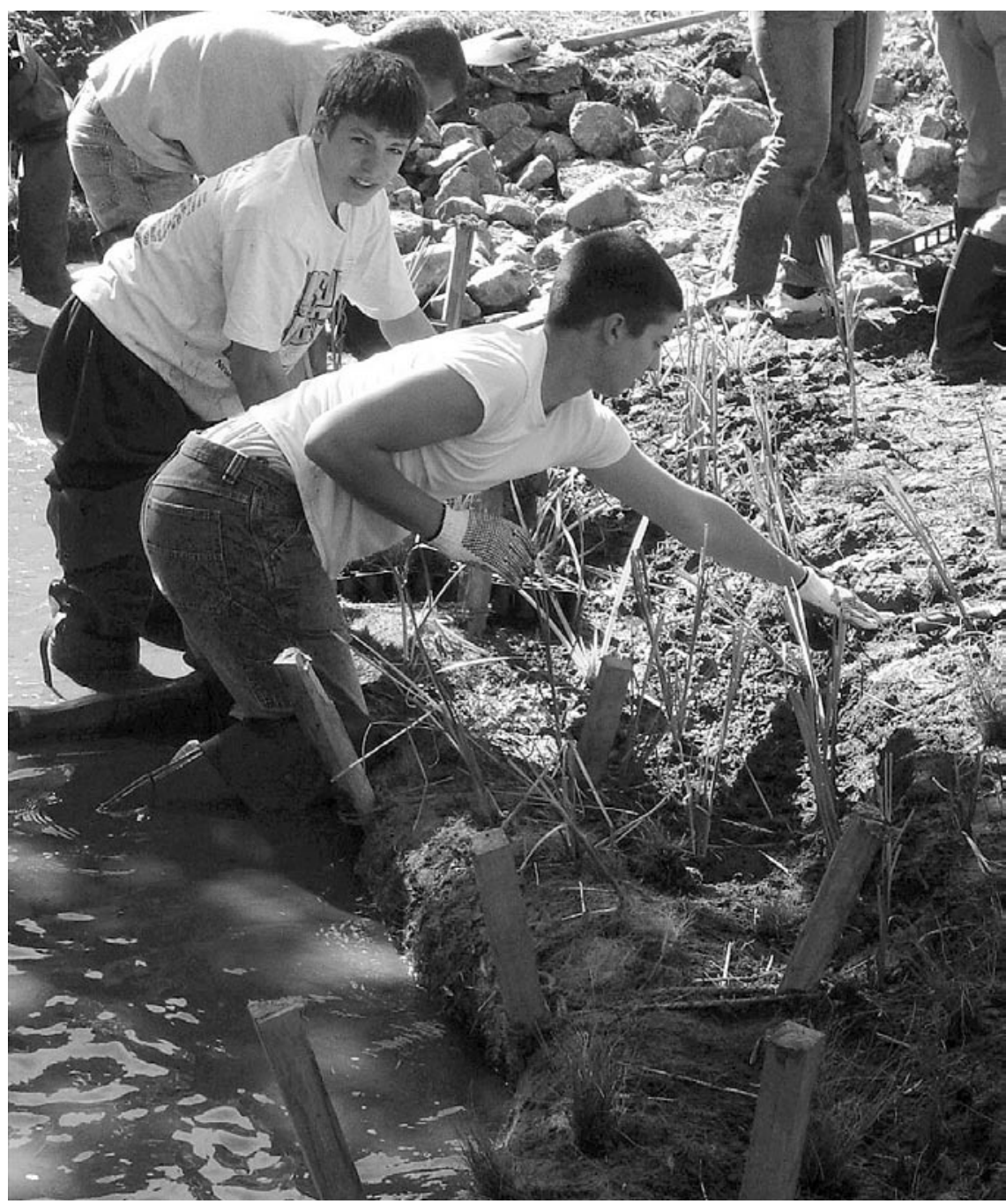

High school biology students Nick Raptis and Tyler Perrelle of Mahopac High School in Putnam County, New York, worked with artist William Meyer in restoring a section of a stream that flows in front of their high school. The stream work occurred as part of an ongoing stream monitoring project initiated by biology teacher Bob Connick. Photo by William Meyer

The photo presented here is one of a series developed by the arts and environmental group Ala Plastica, which worked to expose the consequences of the catastrophe on the environment and local community. Between January 18th and February 10th Ala Plastica developed a qualitative assessment, including a field survey, aerial observation, and satellite imagery analysis of the coastal area in coordination with the local authority and a local UNESCO agency.

A priority task for Ala Plastica was to evaluate the consequences on the ecosystem from different points of view. They organized a riverside survey team

\section{Transfer Project}

William Meyer III, in collaboration with Robert J. Kent, NY Sea Grant, Cornell University and Margery Daughtrey, Department of Plant Pathology, Cornell University

The Transfer Project seeks to establish among middle school students a sense of place through a personal investment in the natural world. Middle school students participating in a natural science class visited and photographed preserved fragments of their native landscape, a process through which they gained an understanding of native plant communities on Long Island. Meyer, an artist from the project, then worked with students to select several photographs and to identify the plants and their communities in order to transfer them to a collaborative native plant garden. The students worked with the artist to reconstruct the chosen photographs in Art Sites' outdoor exhibition space.

Students' individual selections of particular plants and places in the landscape broaden the value of this project. There are multiple layers and intersecting components to the project that involve social interpretation of nature, community, ecology, and art making. Community partners included educators, native plant specialists, cooperative extension professionals, plant nurseries, state park officials, and parents. This participation by local professionals helped develop looping patterns connecting the students to the community.

\section{Concrete Jungle}

\section{Richard Kirk Mills}

I always relied upon both the solace and joy offered by my connection to and observation of the natural world. I attribute my sensitivity to place - and in particular "the wet landscape" - to my first happy years in East Rockaway, Long Island, on an estuary on the south shore where I boated, explored, swam, 


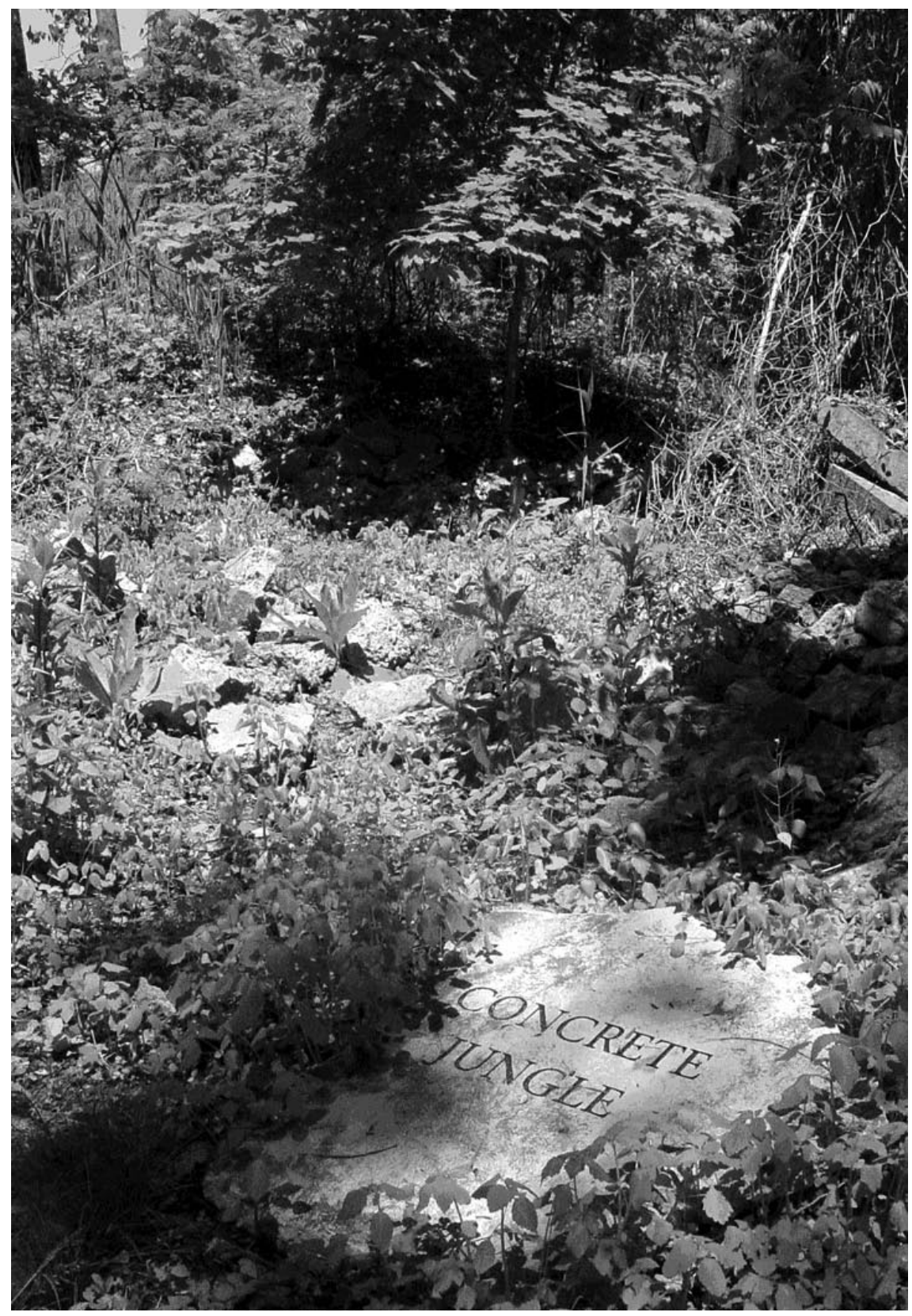

"Concrete Jungle," a trailside sign for the Teaneck Creek Conservancy made from recycled highway concrete debris ("New Jersey Rubblestone"), 2004. Photo courtesy of Richard Kirk Mills

and fished. Bearing witness to the rapid decline of water quality as Nassau County hyper-developed in the 1950 s was also part of this experience.

Starting literally in my backyard, my work evolved into an activist aesthetic that attempts to reconnect people to places (and hence, stewardship) through a public art process of responsive interpretation, education, and community engagement. I began to research local environmental, topographic, and cultural place histories, all of which formed the basis for my our environment. I included newly found skills as a presenter before regulatory agencies as part of an aesthetic arsenal. I saw a shift from a go-italone mentality of the studio/gallery system to an emphasis on a collaborative approach with all segments of the local community.

As Teaneck Creek Conservancy artist in residence for six years, I worked with the local education, environmental, and arts communities, and state and county governments on a team of artists, landscape architects, engineers, grant writers, funders, and urban wetland scientists to reclaim and re-story this 46-acre former New Jersey landfill. A 1.2 mile trail system and place-responsive art program are among components we envisioned. Concrete Jungle captions one of many piles of highway concrete debris dumped on site. Artists working at the Conservancy continue to recycle this dumped "New Jersey Rubblestone."

\section{Prima Lingua}

\section{Jackie Brookner}

I collaborate with ecologists, design professionals, local communities, policy makers, and government agencies on water remediation and public art projects for wetlands, rivers, streams, and stormwater runoff. My living sculptures, which I call Biosculptures $^{\mathrm{TM}}$, integrate sculpture's conceptual, metaphoric, and aesthetic capacities with ecological revitalization and serve as focal points for building community awareness.

These sculptures purify water and air while demonstrating how there is no waste in healthy natural systems. As the water flows over the sculptures, the mosses and carefully chosen plants and their associated bacteria transform waste and toxins into food. Pollutants become resources for metabolism. Aquatic organisms such as fish, snails, and plants enrich these sculpted wetland ecosystems.

Why are we treating stormwater as waste, when in fact, we could be 


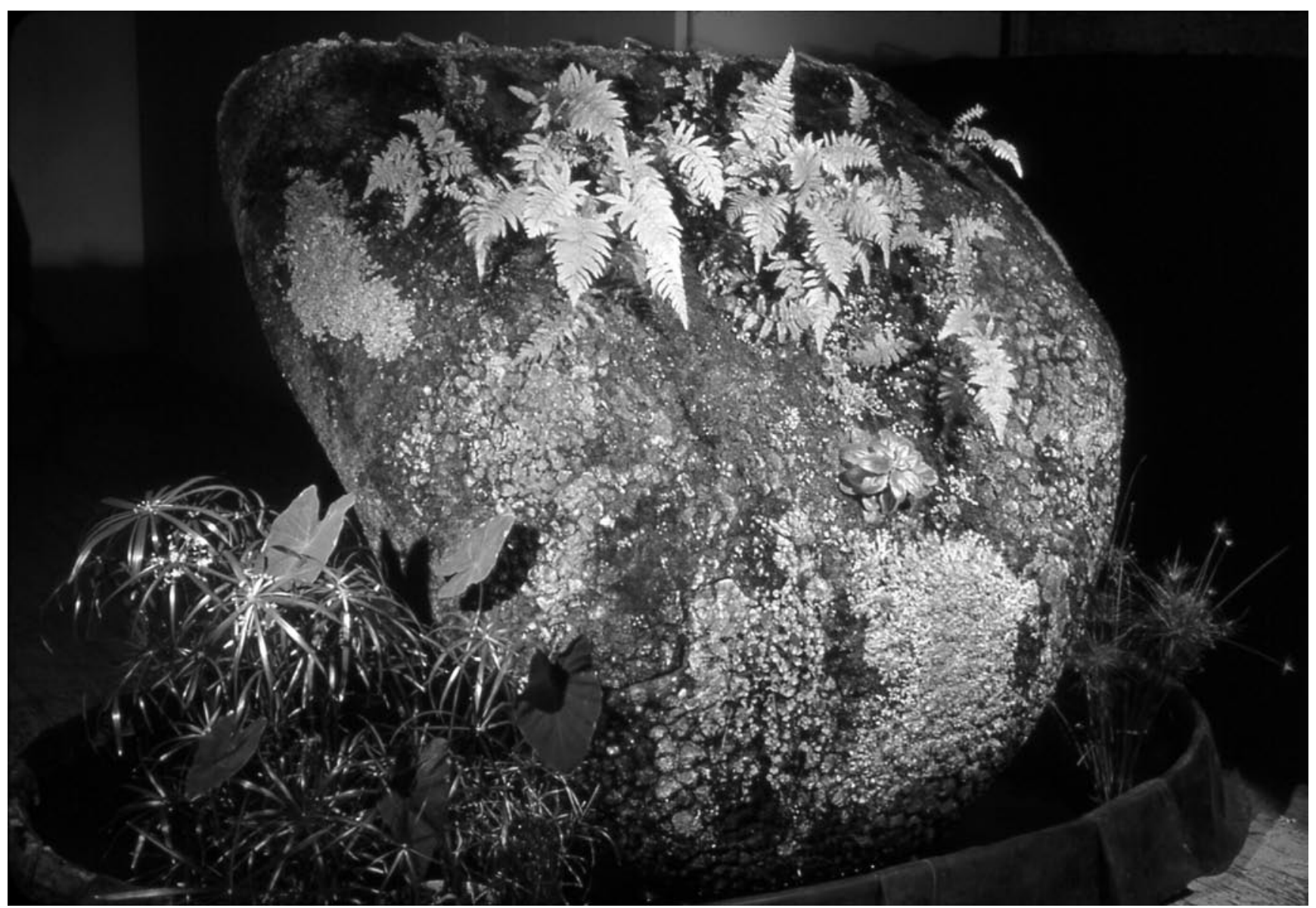

Prima Lingua is a monstrously large tongue that licks the polluted water in which it stands. It is constructed of volcanic rock, concrete, mosses, ferns, wetland plants, water, fish, snails, steel, and rubber. The mosses, liverworts, and other plants that live on the surface help clean air as well as filter the water. Mosses are biochemical filters capable of absorbing even heavy metals, while the porous concrete substructure physically removes particulates. Photo by Jackie Brookner

using it to create lush environments? Instead of getting the water out of sight into drains as fast as possible, we could reveal the hydrology of a place to create expressive and multifunctional public spaces. To effect change of this sort, in addition to doing things differently on the practical level, I believe it is also necessary to examine the unconscious collective cultural assumptions and fears that underlie policy and choices that shape our values and constrain our actions. One of my roles as an artist is to help in this process. I work to expose and examine assumptions about value, about how we see ourselves as a species, about our responsibilities to each other and to the other species on the planet, and to unearth fears that underlie our extremely ambivalent relationship to matter, our bodies, waste, and ultimately death.

\section{Penetration and Transparency Morphed}

Mierle Laderman Ukeles with Kathy Brew and Roberto Guerra

For over 50 years, Staten Island's Fresh Kills Landfill (the world's largest, it is said) received New York City's municipal garbage and was also the repository for the debris of the attacked World Trade Center. An incredible place of awesome scale, almost three Central Parks big, the landfill is filled with 150 million tons of rejected urban detritus, yet full of the promise of transformation into a safe, environmental urban park. Between 2001 and 2002, Ukeles produced a video artwork about Fresh Kills called "Penetration and Transparency Morphed," with videomakers Roberto Guerra and Kathy Brew.
In the piece, two projectors show the stunning physicality of this postindustrial landscape in the midst of environmental closure, still inaccessible, yet beckoning the viewer to enter and wander via this video. This big picture is countered with in-depth interactions on four monitors that feature 21 "pathfinders," different experts involved in the work of regenerating Fresh Kills. The pathfinders include the director of landfill engineering, his infrastructure technicians, city planners, landscape theoreticians, cultural critics, ecologists, local officials, and many Staten Island residents of all ages. The work aims to address the multilayered complexity of the future of Fresh Kills' 2,200 acres. It is a nonlinear, purposely fragmented journey of learning that leads to multiple paths - the future for Fresh Kills is still open. The artist continues to 


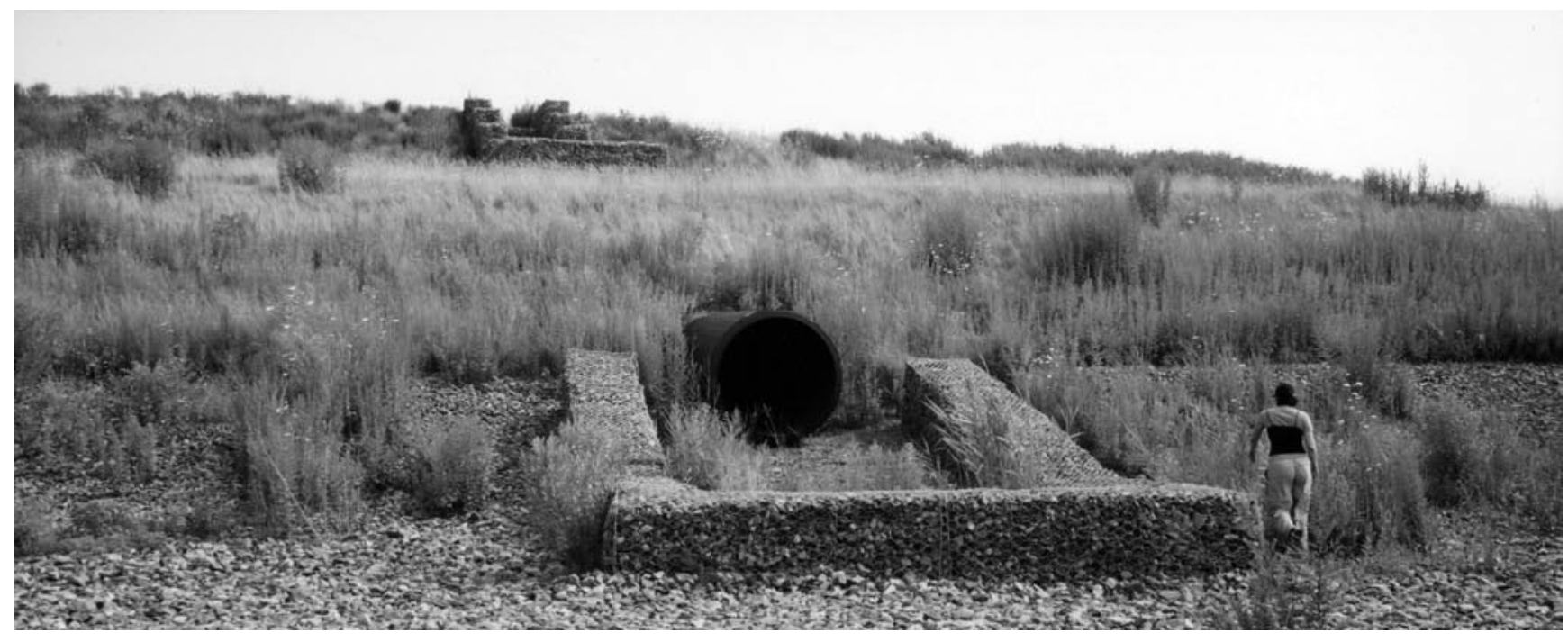

A still photo of the Fresh Kills landfill drainage system taken from a six-channel video installation featuring the many people involved in envisioning the future of the country's largest land fill. Photo courtesy of Ronald Feldman Fine Arts

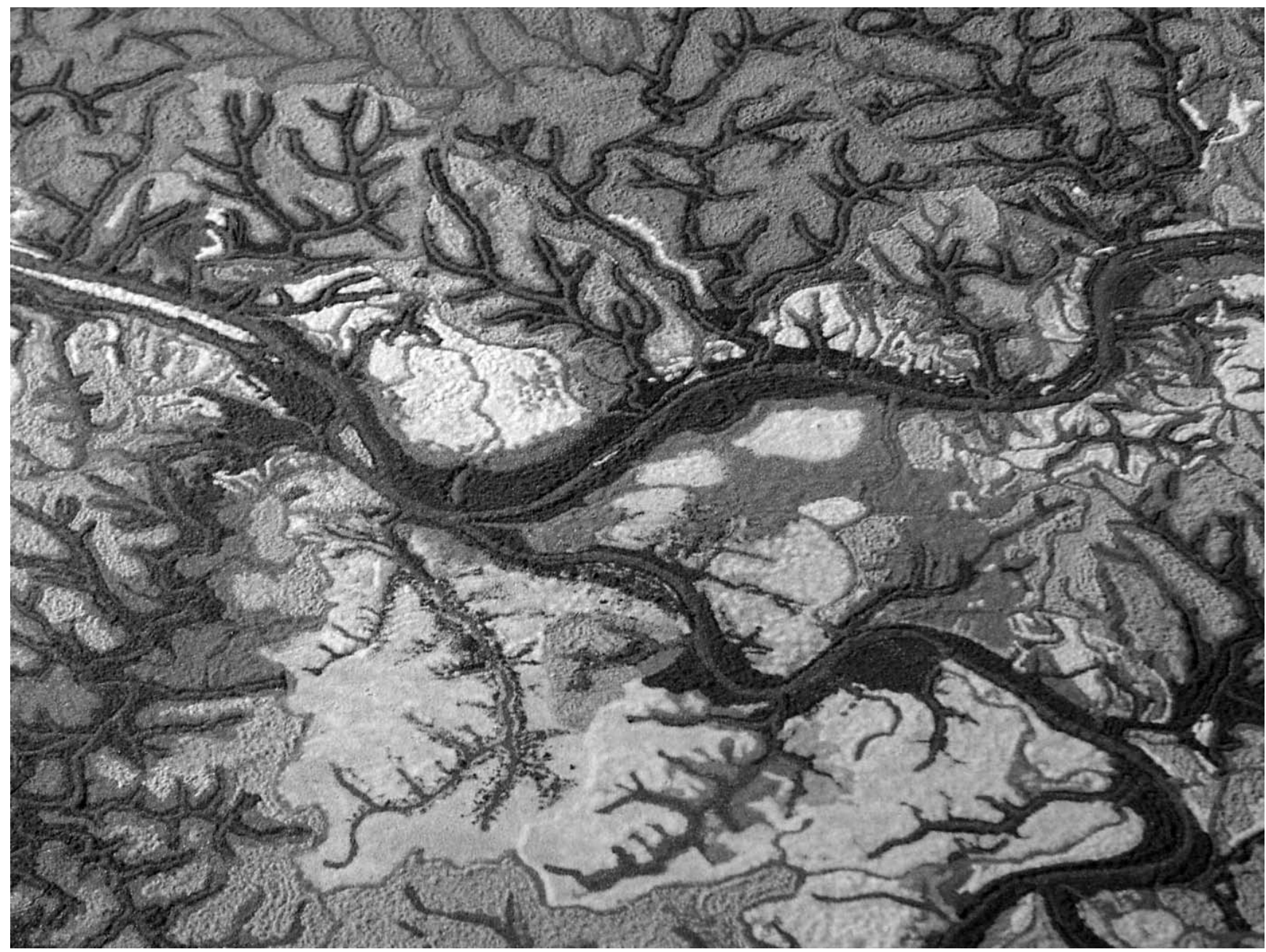

Seeking to represent the body of work done on 3 Rivers 2 nd Nature-which includes 15 volumes of reports, and records of the social, ecological, and political dialogue that defines the project-the artists created a sand mandala as an archetypal template to present their work to aid in the recovery of the natural ecosystems of Allegheny County. Photo courtesy of Reiko Goto Collins and Tim Collins 
work on this commission to design public art elements of Fresh Kills and to contribute to the Fresh Kills Master Plan (now in process) as a member of the design team.

\section{The 3 Rivers 2nd Nature Project}

Reiko Goto Collins, Tim Collins and Noel Hefele

The 3 Rivers 2nd Nature project addressed the meaning, form, and function of public space and nature in Allegheny County, Pennsylvania, the region that encompasses the former steel industry capital of the United States, Pittsburgh. The three major rivers, the Allegheny, the Monongahela, and the Ohio, and 53 streams that flow through Allegheny County, Pennsylvania, define the five-year-long scope of 3 Rivers 2nd Nature. The project focused on water quality and urban riverbanks, the "blue and green infrastructure" of the recovering landscape.

The work effort involved creating partnerships to accomplish interdisciplinary analysis, spatial mapping, and concept design. The work culminated in an ecological design plan and a water quality policy report that analyzed alternatives for ongoing water quality sampling. Objectives included identifying opportunities for ecological restoration, understanding the history and basis for cultural restoration, and conducting a public dialogue about project findings. The project team organized the "Monongahela Conferences" and a subsequent 2005 exhibition, "Groundworks," which examined the artist's role in social and environmental change (http://3r2n. cfa.cmu.edu/). In this project, research was applied as strategic knowledge with accompanying outreach programs designed to enable creative public advocacy and change.

For more examples of artists' work in Called to Action please visit the gallery page at: www.ecologicalrestoration.info.

\section{Acknowledgments}

This show was made possible by the ideals, dedication, and generosity of all involved. I would especially like to thank Glynis M. Berry, A.I.A., LEED AP and Hideaki Ariizumi, A.I.A., studio a/b architects and Art Site's owners. There was always the sense that there was a cause bigger than each of us and that we were just spreading the word. All the artists generously committed to the show: Ala Plastica, Bob Braine and Leslie Reed, Jackie Brookner, Mel Chin, Reiko Goto and Tim Collins, Helen and Newton Harrison, Stacy Levy, William T. Meyer, Richard Kirk Mills, Aviva Rahmani, Hope Sandrow, and Mierle Ukeles. The roundtable participants were invaluable: Robert J. Kent, Senior Extension Associate with NY Sea Grant of Cornell University Research and Extension Center, who participated on multiple levels; Barbara Branca, NY Sea Grant; Maureen Cullinane, North Fork Audubon; Margery Daughtrey, Cornell University, Plant Pathology; Carrie Meek Gallagher, Director Suffolk County Dept. of Environment and Energy; Chris Pickerell, Habitat Restoration Specialist, Cornell University; Bob Ghosio, Southold Town Trustee; Marion Sumner, Peconic Land Trust; Mark Terry, Southold Town Senior Environmental Planner; and Amei Wallach, Art Critic. Sincere thanks to all.

Lillian Ball is an artist and environmental activist working in New York. Community participation and education are integral parts of her working method on issues ranging from land preservation and restoration to storm water mitigation and climate change.Lillian Ball, ballstudio@ thing.net, http://www.lillianball.com. 